\title{
K. Reise $\cdot$ F. Buhs \\ Reply to the comment of Damm and Neudecker (1999): long-term decline in epibenthic fauna of tidal channels near the island of Sylt in the northern Wadden Sea
}

Received: 15 November 1998 / Accepted: 26 April 1999

In a descriptive study on epifauna in tidal channels of the Wadden Sea (Buhs and Reise 1997) we included in the discussion a table listing species with their frequencies of occurrence comparing our study with earlier ones in the same region. The content of this table was critically examined by Damm and Neudecker (1999). Although we do not agree with all of their comments, we generally appreciate their detailed analysis, admit that this table was deficient, and respond here with an improved version (Table 1). Principally, we include all taxa properly retained by a traditional oyster dredge. On oyster grounds this gear invariably accumulates abundant mollusc shells and occasionally masses of hydroids, bryozoans, sponges, algae or dead eelgrass. As soon as the net bag is partially filled with such material, any kind of small organisms may be retained, regardless of the mesh size used. In an attempt to standardize this effect, we added to the $6-\mathrm{cm}$ mesh of iron rings an inlet net bag with $1-\mathrm{cm}$ meshes. In this way potentially we could retain more smaller organisms than Möbius (1893), Hagmeier and Kändler (1927) and Hagmeier (1941) with their gear. However, we excluded all small, mobile organisms (i.e., most polychaetes, peracarid crustaceans, nudibranchs) from the comparison because these records are assumed to be too fortuitous, depending on the amount of by-catch material, handling of the dredge and care in sorting the retained material. We further excluded from the comparison some hydroid and bryozoan taxa because these were incompletely analyzed (Hagmeier and Kändler 1927, p. 15). Occasionally, the dredge digs into the sediment, catching infaunal species. These have also been excluded from our study on epifauna.

None of these decisions could potentally bias the comparison towards an overrepresentation of the earlier studies. More critical is the transformation of verbal

K. Reise $(\varangle) \cdot$ F. Buhs

Alfred-Wegener-Institut für Polar- und Meeresforschung,

Wattenmeerstation Sylt, D-25992 List, Germany

e-mail: kreise@awi-bremerhaven.de

Tel.: +49-4651-956-110; Fax: +49-4651-956-200 statements on frequencies of occurrence in dredge hauls or even on abundances of species (Möbius 1893; Hagmeier and Kändler 1927; Hagmeier 1941) into categories to be used in a comparison with our data. In Table 1 we adopted a scheme that is less prone to subjective decisions than the one in Table 5 by Buhs and Reise (1997). The category 1 refers to species recorded at one to three sites only, category + to species at $>3$ but less than half of the sites, and category ++ to species found at half or more of the sites. When information on a recorded species was insufficient for categorization, this was noted by $x$. The number of organisms retained by individual hauls is not considered in this comparison, but comments are made when mass occurrences were noted.

In contrast to earlier comparative studies from the same region when exactly the same sites of former sampling were revisited (Riesen and Reise 1982; Reise and Schubert 1987; Reise et al. 1989), the study by Buhs and Reise (1997) was not intended to document long-term developments in the epifauna of tidal channels. However, we feel that a subset of our data, referring to tidal channels north and south of the island of Sylt at a depth of approximately $5 \mathrm{~m}$, is still well suited for such a comparison. Most of Möbius' records refer to this area. Hagmeier and Kändler (1927) and Hagmeier (1941) give exact localities, and our survey covers them all except for a few landward oyster beds in the Hörnum-Tief area. No substantial records originate from the latter. The average depth below low tide level of the former oyster beds near Sylt was $3.3 \mathrm{~m}$, with a range of 0.3 to $7.8 \mathrm{~m}$ (see Möbius 1893). Thus, our choice of an average sampling depth of $5 \mathrm{~m}$ seems to be appropiate for the purpose of comparison.

Table 1 shows that nine species present in both earlier periods of investigation were absent in our recent period, and five other species show higher frequencies of occurrence in both earlier periods compared to the recent one. Conversely, no species were recorded in the recent period that were not found during the earlier investigations, and only three species attained a higher category in the frequency of occurrence in the recent survey compared 
Table 1 Frequencies of epifaunal occurrences in tidal channels near Sylt; comparison of three periods (Möbius 1893; Hagmeier and Kändler 1927; Hagmeier 1941; Buhs and Reise 1997). 0 Not encountered; 1 = at one to three (few) sites; + at some but not most sites; $++=$ at most $(\geq 50 \%)$ sites; $x$ encountered but frequency over sites not indicated

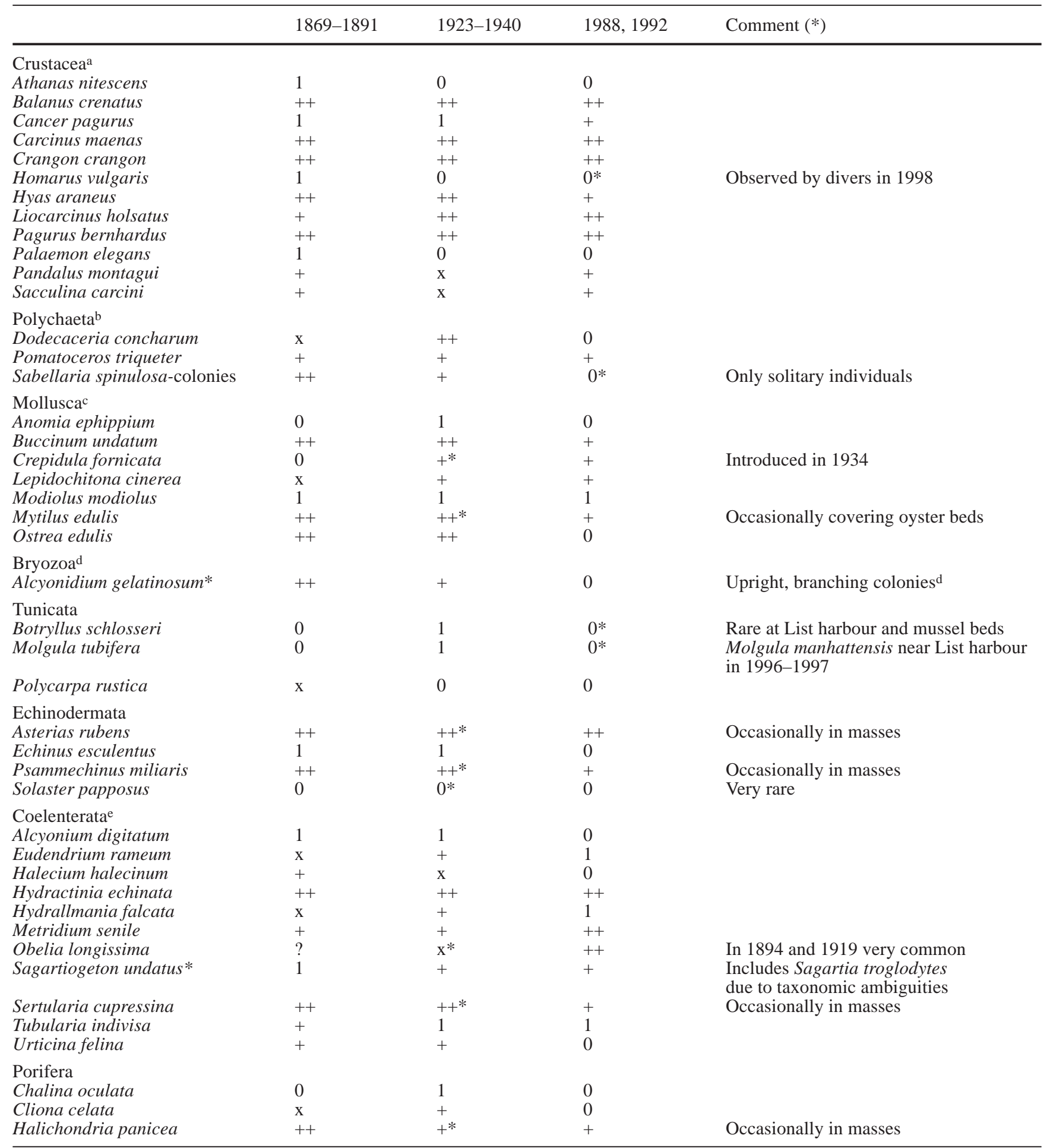

a Paracarid and other small Crustacea excluded

b Sessile species only because mobile polychaetes usually escape the dredge

c Endobenthic bivalves and nudibranchs excluded because not properly obtained or retained with a dredge

d Within the Bryozoa, taxonomic confusion occurred. We only refer to Alcyonidium gelatinosum as an upright, branching colony as depicted on p. 29 in Hagmeier and Kändler (1927), usually growing on mollusc shells. It also occurs encrusting on shells of hermit crabs, but this occurrence is not considered here

e Thirteen further hydrozoan species are recorded but incomplete taxonomic analyses prevent comparison 
to both earlier ones. Comparisons between any other combination of periods never revealed more than four such differences. The total number of species listed in Table 1 for the first period is 37 , for the second is 39 and for the recent period only 26 .

We conclude from this comparison that a significant decline in epifaunal diversity and frequency has occurred since the first half of the twentieth century. This agrees with similar comparisons conducted by Reise (1982), Riesen and Reise (1982), Reise and Schubert (1987) and Reise et al. (1989), and should not be confused with the other result of these studies that infaunal abundances and species densities may have increased since Hagmeier and Kändler (1927) and Wohlenberg (1937).

Our recent dredging on epifauna in the region of former oyster beds in the northern Wadden Sea comprises a period from 1980 to 1992 when the above-cited studies plus Reise and Bartsch (1990) are taken together, and thus constitutes a time span similar to that of the earlier two periods. Ongoing surveys since 1992 also agree with Table 1 (own unpublished data). We therefore regard our conclusion that the epifauna of the tidal channels around Sylt became impoverished during recent decades as a robust result.

\section{References}

Buhs F, Reise K (1997) Epibenthic fauna dredged from tidal channels in the Wadden Sea of Schleswig-Holstein: spatial patterns and a long-term decline. Helgol Meeresunters 51:343-359

Damm U, Neudecker T (1999) Comment: Epibenthic fauna dredged from tidal channels in the Wadden Sea of SchleswigHolstein: spatial patterns and a long-term decline. Helgol Mar Res 53:141-142

Hagmeier A (1941) Die intensive Nutzung des nordfriesischen Wattenmeeres durch Austern- und Muschelkultur. Z Fisch 39: $105-165$

Hagmeier A, Kändler R (1927) Neue Untersuchungen im nordfriesischen Wattenmeer und auf den fiskalischen Austernbänken. Wiss Meeresunters (Helgol) 16:1-99

Möbius K (1893) Über die Tiere der schleswig-holsteinischen Austernbänke, ihre physikalischen und biologischen Lebensverhältnisse. Sber Preuss Akad Wiss 7:33-58

Reise K (1982) Long-term changes in the macrobenthic invertebrate fauna of the Wadden Sea: are polychaetes about to take over? Neth J Sea Res 16:29-36

Reise K, Bartsch I (1990) Inshore and offshore diversity of epibenthos dredged in the North Sea. Neth J Sea Res 25:175-179

Reise K, Schubert A (1987) Macrobenthic turnover in the subtidal Wadden Sea: the Norderaue revisited after 60 years. Helgol Meeresunters 41:69-82

Reise K, Herre E, Sturm M (1989) Historical changes in the benthos of the Wadden Sea around the island of Sylt in the North Sea.- Helgol Meeresunters 43:417-433

Riesen W, Reise K (1982) Macrobenthos in the subtidal Wadden Sea: revisited after 55 years. Helgol Meeresunters 35:409-423

Wohlenberg E (1937) Die Wattenmeer-Lebensgemeinschaften im Königshafen von Sylt. Helgol Meeresunters 1:1-92

Communicated by K. Lüning 